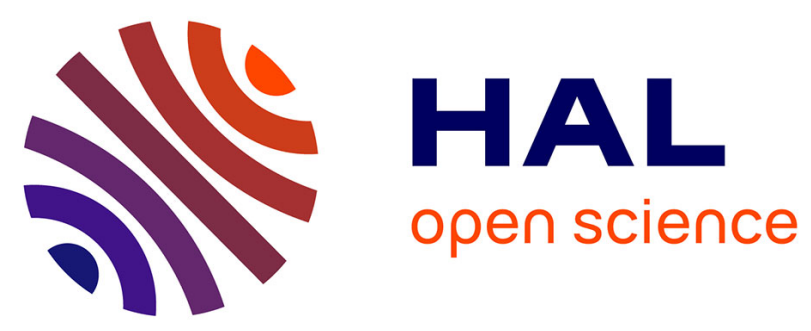

\title{
A FEM comparative analysis of the thermal efficiency among floors made up of clay, concrete and lightweight concrete hollow blocks
}

J.J. del Coz Díaz, P.J. García Nieto, J. Domínguez Hernández, F.P. Álvarez Rabanal

\section{To cite this version:}

J.J. del Coz Díaz, P.J. García Nieto, J. Domínguez Hernández, F.P. Álvarez Rabanal. A FEM comparative analysis of the thermal efficiency among floors made up of clay, concrete and lightweight concrete hollow blocks. Applied Thermal Engineering, 2010, 30 (17-18), pp.2822. 10.1016/j.applthermaleng.2010.07.024 . hal-00678804

\section{HAL Id: hal-00678804 https://hal.science/hal-00678804}

Submitted on 14 Mar 2012

HAL is a multi-disciplinary open access archive for the deposit and dissemination of scientific research documents, whether they are published or not. The documents may come from teaching and research institutions in France or abroad, or from public or private research centers.
L'archive ouverte pluridisciplinaire $\mathbf{H A L}$, est destinée au dépôt et à la diffusion de documents scientifiques de niveau recherche, publiés ou non, émanant des établissements d'enseignement et de recherche français ou étrangers, des laboratoires publics ou privés. 


\section{Accepted Manuscript}

Title: A FEM comparative analysis of the thermal efficiency among floors made up of clay, concrete and lightweight concrete hollow blocks

Authors: J.J. del Coz Díaz, P.J. García Nieto, J. Domínguez Hernández, F.P. Álvarez Rabanal

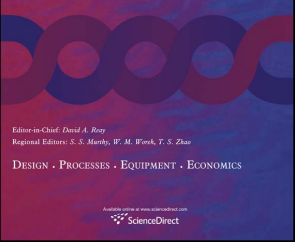

PII:

$$
\text { S1359-4311(10)00307-8 }
$$

DOI: 10.1016/j.applthermaleng.2010.07.024

Reference: ATE 3183

To appear in: Applied Thermal Engineering

Received Date: 7 January 2010

Revised Date: 21 July 2010

Accepted Date: 25 July 2010

Please cite this article as: J.J. del Coz Díaz, G. Nieto, D. Hernández, F.P. Álvarez Rabanal. A FEM comparative analysis of the thermal efficiency among floors made up of clay, concrete and lightweight concrete hollow blocks, Applied Thermal Engineering (2010), doi: 10.1016/j.applthermaleng.2010.07.024

This is a PDF file of an unedited manuscript that has been accepted for publication. As a service to our customers we are providing this early version of the manuscript. The manuscript will undergo copyediting, typesetting, and review of the resulting proof before it is published in its final form. Please note that during the production process errors may be discovered which could affect the content, and all legal disclaimers that apply to the journal pertain. 


\title{
A FEM comparative analysis of the thermal efficiency among floors made up of clay, concrete and lightweight concrete hollow blocks
}

\author{
J. J. del Coz Díaz ${ }^{1, *}$, P. J. García Nieto ${ }^{2}$, J. Domínguez Hernández ${ }^{3}$, F.P. Álvarez \\ Rabanal $^{1}$ \\ ${ }^{1}$ Department of Construction, University of Oviedo, 33204 Gijón, Spain \\ ${ }^{2}$ Department of Mathematics, University of Oviedo, 33007 Oviedo, Spain \\ ${ }^{3}$ Department of Mechanical Engineering, University of Zaragoza, 50018 Zaragoza, Spain
}

\begin{abstract}
This paper presents a comparative nonlinear thermal analysis for a total of eighteen different in situ cast floors varying both the constituent materials of the hollow blocks (clay, concrete and lightweight concrete) and the shape and number of recesses (six different block types) using the finite element method (FEM). Based on the non-linear thermal analysis of the different configurations by FEM and considering both upward and downward heat flows, it is possible to choose the best candidate floor from the thermal point of view. Mathematically, the nonlinearity is due to the radiation boundary condition inside the recesses of the blocks. The comparative analysis of the floors is carried out from the finite element analysis through the two important parameters: the average mass overall thermal efficiency and the equivalent thermal conductivity. Finally, the results and conclusions reached in this work are exposed.
\end{abstract}

Keywords: Hollow block; Finite element modelling; Non-linear complex heat transfer; Energy savings.

\section{Introduction}

In recent years, many researchers have studied the thermal behavior of the different construction elements in buildings, such as: walls, roofs, floors, windows and so on [17]. This study seeks responses to the following questions: what is the difference of the thermal performance when the number and shape of the block recesses is varied? And, what is the best constituent material of blocks to obtain the biggest energy savings?

It is evident that there are many differences between construction elements in building today [8]. However, to the best of our knowledge, there is a little information available concerning the thermal comparative behavior between the same or similar blocks made up of different constituent materials. Thus, two purposes of this study were proposed: firstly, this work provides the information through numerical studies that it is possible to obtain the thermal performance of complex structural elements and secondly, a comparative analysis of floors made up of different materials and recesses was conducted, which will be assist in the recommendation of the sustainable and ecological products, with respect to the energy efficiency, for industrial and housing in the world in the future.

\footnotetext{
* Corresponding author. Tel.: +34-985-182042; fax: +34-985-182433.

E-mail address: juanjo@constru.uniovi.es (J. J. del Coz Díaz).
} 
1 During the last years, experimental and numerical studies have been developed to study 2 two and three dimensional heat transfer phenomena in construction elements made up of 3 hollow blocks [1-3]. Most interests are involved in the optimization process applied to 4 obtain the best design from the thermal point of view in case of clay and lightweight spanning slabs for internal floors is carried out, taking into account both upward and downward heat flows, in which all heat transfer processes for every constituent materials are considered [9-15]: conduction, convection and radiation inside enclosures.

The FEM [16-20] is a good choice for solving the heat partial differential equation over complicated domains like hollow blocks, when the domain changes, when the constituent materials vary, when the desired precision varies over the entire domain, or even when the solution is continuous but not derivable. This complex problem was solved in this work by means of the finite element analysis.

\section{Geometry and materials considered in the multilayer floor}

In Spanish industrial and housing buildings, different types of multilayer floors are used [7]. In this way, the most used construction solution is the in situ cast floor with oneway spanning slabs. Therefore, this work is applied to the thermal study of this type of floors when different bricks and different constituent materials are used, in order to find the best one from the thermal point of view.

Fig. 1. Structural components of an in situ cast floor with one-way spanning slabs.

The usual constituent components of this kind of floor are as follows (see Fig. 1): plant produced concrete, weldmesh reinforcement, prestressed concrete joists, multi-holed blocks and gypsum plaster (or other different covering materials). The physical properties of the constituent materials of the in situ cast floor are indicated in Table 1 [11-12].

\section{Table 1}

Physical properties of the constituent materials.

Fig. 2. Geometrical models and dimensions (in millimetres) of the clay multi-holed blocks $C F 1, C F 2, C F 3, C F 4, C F 5$ and $C F 6$.

In order to study the thermal behavior of the in situ cast floors made up of different multi-holed blocks, we have modeled a total of eighteen different types of floors keeping the same overall dimensions and varying, on the one hand, the number of recesses of the blocks (see Fig. 2): $C F 1$ (three recesses), $C F 2$ (six recesses), $C F 3$ (nine recesses), CF4 (four recesses), CF5 (eight recesses) and CF6 (twelve recesses). On the other hand, we have considered three different constituent materials for the multiholed blocks: concrete, lightweight concrete and clay. 
1 Secondly, we have built an entire floor with each one of the eighteen different blocks 2 described above. The one-way spanning slab is made of five multi-holed blocks with 3 four joists, including the weldmesh reinforcement, the plant-produced concrete and the 4 gypsum plaster (see Fig. 3).

Fig. 3. Two-dimensional FE in situ cast floor: overall view (upper) and a detail (lower).

The minimum thickness of the intermediate bulkheads is $15 \mathrm{~mm}$ for both plantproduced and lightweight concrete blocks, and $8 \mathrm{~mm}$ for the clay blocks. This fact is a consequence of the greater mechanical resistance of the clay comparing with the other two materials studied: normal concrete and lightweight concrete. Finally, it is possible to classify the blocks $C F 1$ to $C F 6$ from the number of intermediate bulkheads. Therefore, there are two main groups [7]:

- The first group has two intermediate bulkheads including blocks $C F 1$ to $C F 3$.

- The second group has three intermediate bulkheads and it includes blocks $C F 4$ to $C F 6$.

\section{FEM results and discussion}

The above in situ cast floors made up of different multi-holed blocks are discretized by the FEM [16-18] and then the thermal behavior of reinforced concrete one-way spanning slabs for internal floors is calculated.

In order to check the thermal performance of the different types of multiholed ( $C F 1$ to $C F 6$ ), eighteen floors (one per each type of block) have been considered. Then, we have built the two-dimensional finite element model, using a two-dimensional 8-node quadrilateral finite element for the solid area of blocks to simulate the thermal conduction phenomenon, a one-dimensional 3-node (plus an extra node) finite element for the recesses of blocks to calculate the thermal convection phenomenon and, finally, a one-dimensional 3-node finite element in order to solve the thermal radiation phenomenon inside the recesses of blocks [21-22] (see Fig. 3 above).

With respect to the external thermal boundary conditions, we have taken the following ones [23]:

- Downward heat flow: a $q / A=10 \mathrm{~W} / \mathrm{m}^{2}$ heat flow in the upper floor side, a $h_{l}=1 / R_{s l}=5.88 \mathrm{~W} / \mathrm{m}^{2} \mathrm{~K}$ film coefficient in the lower floor side, a $R_{s u}=0.17$ $\mathrm{m}^{2} \mathrm{~K} / \mathrm{W}$ surface resistance in the upper floor side and a $273 \mathrm{~K}$ ambient temperature.

- Upward heat flow: a $q / A=10 \mathrm{~W} / \mathrm{m}^{2}$ heat flow in the lower floor side, a $h_{u}=1 / R_{s u}=10 \mathrm{~W} / \mathrm{m}^{2} \mathrm{~K}$ film coefficient in the upper floor side, a $R_{s l}=0.10$ $\mathrm{m}^{2} \mathrm{~K} / \mathrm{W}$ surface resistance in the lower floor side and a $273 \mathrm{~K}$ ambient temperature

The internal boundary conditions inside the recesses are as follows [23-24]:

- Downward heat flow: The film convection coefficient inside the recesses in this case is: 


$$
h_{a}=\max \left\{0.12 \times d^{-0.44}, \frac{0.025}{d}\right\}
$$

- Upward heat flow: The film convection coefficient inside the recesses in this case is:

$$
h_{a}=\max \left\{1.95, \frac{0.025}{d}\right\}
$$

where $d$ is the thickness of the recesses in the vertical direction.

Next, the eighteen different FEM models are solved and the temperature distribution is determined (see Fig. 4).

In order to determine the block's thermal performance it is necessary to define two important parameters [3-4]:

- The mass overall thermal efficiency, $e_{\text {thermal_p }}\left(\mathrm{m}^{2} \mathrm{~K} / \mathrm{W} / \mathrm{kg}\right)$ : this parameter is defined as the ratio between the overall thermal resistance and the mass of the block.

- The equivalent thermal conductivity, $\lambda_{\text {equi }}(\mathrm{W} / \mathrm{m} \mathrm{K})$ : it is defined as the ratio between the thickness of the multilayer floor and the thermal resistance.

Both parameteres are calculated from the previous thermal numerical results and they are shown in Fig. 5.

Fig. 4. Temperature distribution in floors made up of hollow block types $C F 3$ (left) and CF6 (right) for the downward heat flow: lightweight concrete ( $\mathrm{a}$ and $\mathrm{b}$ ), normal concrete (c and d), and clay (e and f).

On the one hand, specifically Fig. 5 (left) show the mass overall thermal efficiencies in all analyzed cases, both for downward and upward heat flows, and it is evident that the worst material is the plant-produced concrete (about 0.2 and $0.15 \%$ for downward and upward heat flows, respectively). Moreover, there are several differences between multiholed blocks, being the blocks $C F 1$ and $C F 4$ the worst of them. It is also possible to observe that the best block from the thermal performance point of view is the block CF3 made up of lightweight concrete as the constituent material, since its average value ( $0.3 \%$ and $0.37 \%$ for upward and downward heat flows, respectively) is the biggest one.

Fig. 5. Mass overall thermal efficiency (left) and equivalent thermal conductivity (right) for downward heat flow (upper) and upward heat flow (lower) for the three analyzed materials and six different models.

On the other hand, it is shown the numerical results for the equivalent thermal conductivity in Fig. 5 (right). From the point of view of this parameter, the best blocks is $C F 3$ made up of lightweight concrete.

After examining the results obtained numerically, it can be assumed that the numerical procedure constitutes a reasonable approach to choose the best type of block from the 
thermal point of view. The finite element model used in this work reproduces accurately the heat transfer for in situ cast floors made up of different constituent materials and different recesses with complex shapes.

\section{Conclusions}

In the first place, a numerical thermal analysis technique (by FEM) has been carried out to study eighteen different in situ cast floors, made up of three different constituent materials for the hollow blocks. Taking into account the variation of the dimensions of the recesses, it is possible to modify the thermal efficiency of the blocks and, consequently of the full floor. Based on the mass overall thermal efficiency and the equivalent thermal conductivity, it is possible to select best candidate floor from the thermal point of view.

In the second place, the equivalent thermal conductivity depends on both the number of the vertical and horizontal intermediate bulkheads and the constituent material. Therefore, if the number of horizontal intermediate bulkheads is increased and the material is changed, the thermal transmittance grows more than if the number of vertical intermediate ones does.

Thirdly, the overall heat transfer coefficient increases if material conductivity increases and the number of recesses decrease. The bigger mass overall thermal efficiency, the better thermal insulation and the lower floor's weight. Therefore, the support structure of these floors will be subjected to smaller dead loads and the best block from the average mass overall thermal efficiency point of view was the block $C F 3$.

Finally, there is an increasing interest to use materials with good physical properties with respect to an energy savings, which also fulfil all strength and serviceability requirements for housing and industrial structures. From this point of view, the architect or engineer can use the results shown in this research work to obtain the best candidate floor configuration according to their thermal requirements.

\section{Acknowledgements}

The authors wish to acknowledge the financial support provided by Spanish Ministry of Science and Innovation through the Research Project BIA2008-00058. We also thank to Swanson Analysis Inc. for the use of ANSYS Academic program, the Department of Construction at University of Oviedo and the MAXIT Group.

\section{References}

[1] J.J. del Coz Diaz, P.J. García Nieto, A. Martin Rodriguez, A. Lozano Martinez-Luengas, C. Betegón Biempica, Non-linear thermal analysis of light concrete hollow brick walls by the finite element method and experimental validation, Applied Thermal Engineering 26 (8-9) (2006) 777-786.

[2] A. Bouchair, Steady state theoretical model of fired clay hollow bricks for enhanced external wall thermal insulation, Building and Environment 43 (10) (2008) 1603-1618.

[3] J.J. del Coz Díaz, P.J. García Nieto, C. Betegón Biempica, M.B. Prendes Gero, Analysis and optimization of the heat-insulating light concrete hollow brick walls design by the finite element method, Applied Thermal Engineering 27 (8-9) (2007) 1445-1456. 
[4] J.J. del Coz Díaz, P.J. Garcia Nieto, J.L. Suárez Sierra, C. Betegón Biempica, Nonlinear thermal optimization of external light concrete multi-holed brick walls by the finite element method, International Journal of Heat and Mass Transfer 51 (7-8) (2008) 1530-1541.

[5] L.P. Li, Z.G. Wu, Y.L. He, G. Lauriat, W.Q. Tao, Optimization of the configuration of $290 \times 140 \times 90$ hollow clay bricks with 3-D numerical simulation by finite volume method, Energy and Buildings 40 (10) (2008) 1790-1798.

[6] J.J. del Coz Diaz, P.J. García Nieto, J.L. Suárez Sierra, I. Peñuelas Sánchez, Non-linear thermal optimization and design improvement of a new internal light concrete multi-holed brick walls by FEM, Applied Thermal Engineering 28 (8-9) (2008) 1090-1100.

[7] J.J. del Coz Diaz, P.J. García Nieto, J. Domínguez Hernández, A. Suárez Sánchez, Thermal design optimization of lightweight concrete blocks for internal one-way spanning slabs floors by FEM, Energy and Buildings 41 (12) (2009) 1276-1287.

[8] B. López-Mesa, A. Pitarch, A. Tomás, T. Gallego, Comparison of environmental impacts of building structures with in situ cast floors and with precast concrete floors, Building and Environment 44 (4) (2009) 699-712.

[9] F.P. Incropera, D.P. DeWitt, Introduction to Heat Transfer, Wiley, New York, 2001.

[10] F. Kreith, M. S. Bohn, Principles of Heat Transfer, Thomson-Engineering, New York, 2000.

[11] A.F. Mills, Heat transfer, Prentice Hall, New York, 1998.

[12] W.M. Rohsenow, J.P. Hartnett, Y. I. Cho, Handbook of Heat Transfer, McGraw-Hill Professional, New York, 1998.

[13] H.S. Carslaw, J.C. Jaeger, Conduction of Heat in Solids, Oxford University Press, New York, 1986.

[14] R. Siegel, J. Howell, Thermal Radiation Heat Transfer, Taylor and Francis Group, New York, 2001.

[15] M.F. Modest, Radiative Heat Transfer, Academic Press, New York, 2003.

[16] K.-J. Bathe, Finite element procedures, Prentice-Hall, Englewoods Cliffs, New Jersey, 2007.

[17] O.C. Zienkiewicz, R.L. Taylor, The Finite Element Method: Solid and Fluid Mechanics, Dynamics and Non-Linearity, McGraw-Hill Book Company, London, 1991.

[18] O.C. Zienkiewicz, R.L. Taylor, P. Nithiarasu, The Finite Element Method for Fluid Dynamics, Butterworth-Heinemann, New York, 2005.

[19] R.D. Cook, D.S. Malkus, M.E. Plesha, R.J. Witt, Concepts and Applications of Finite Element Analysis, Wiley, New York, 2001.

[20] J.-M. Bergheau, R. Fortunier, Finite Element Simulation of Heat Transfer, Wiley-ISTE, New York, 2008.

[21] E. Madenci, I. Guven, The Finite Element Method and Applications in Engineering using ANSYS, Springer, Berlin, 2007.

[22] S. Moaveni, Finite Element Analysis Theory and Application with ANSYS, Prentice Hall, New York, 2007.

[23] UNE-EN ISO 6946, Elements and construction components. Resistance and thermal transmittance: Calculation method, AENOR, Madrid, 1997.

[24] UNE-EN-1745, Masonry and masonry products. Methods for determining design thermal values. AENOR, Madrid, 2002. 
Table 1

Physical properties of the constituent materials.

\begin{tabular}{lcc}
\hline \multicolumn{1}{c}{ Item } & $\begin{array}{c}\text { Density } \\
{\left[\mathrm{kg} / \mathrm{m}^{3}\right]}\end{array}$ & $\begin{array}{c}\text { Conductivity } \lambda \\
{[\mathrm{W} / \mathrm{m} \mathrm{K}]}\end{array}$ \\
\hline Plant-produced concrete & 2,200 & 1.600 \\
Weldmesh reinforcement & 7,850 & 60.000 \\
Prestressed concrete joist & 2,200 & 1.600 \\
Clay & 1,500 & 0.510 \\
Lightweight concrete & 1,000 & 0.347 \\
Gypsum plaster & 1,100 & 0.280 \\
\hline
\end{tabular}




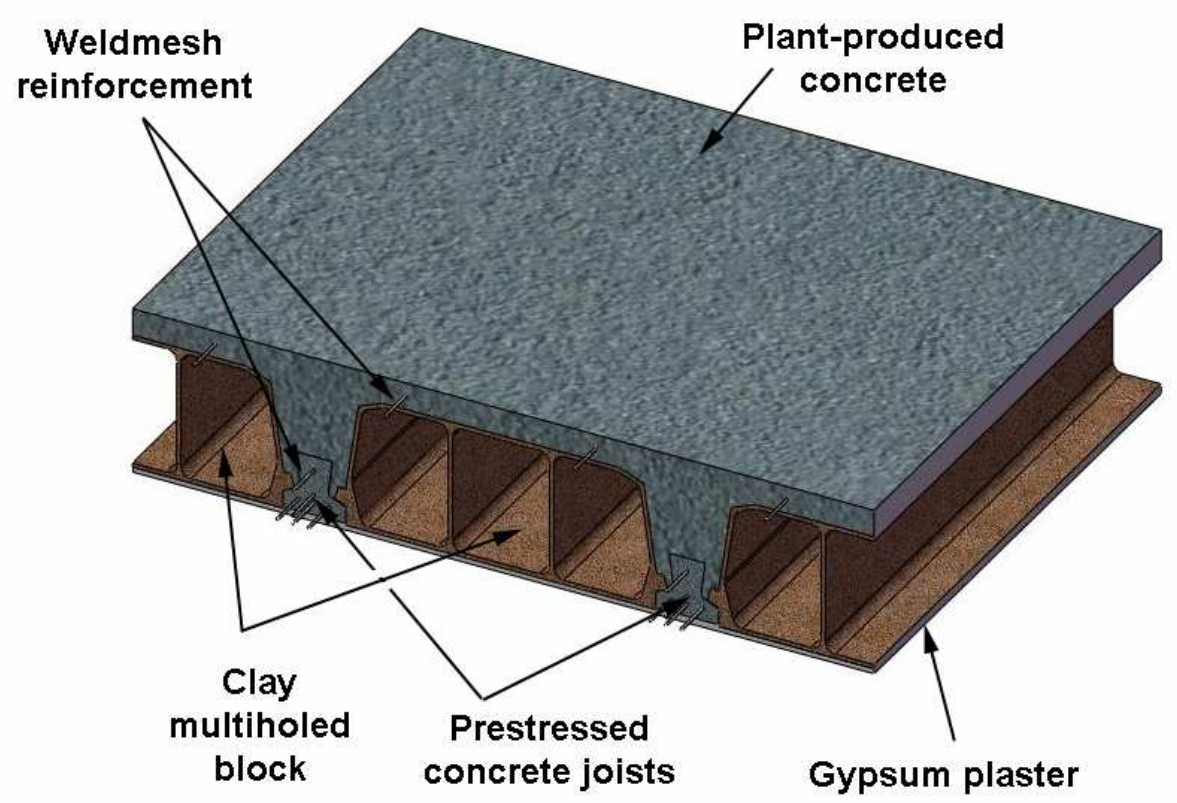

Fig. 1. Structural components of an in situ cast floor with one-way spanning slabs. 


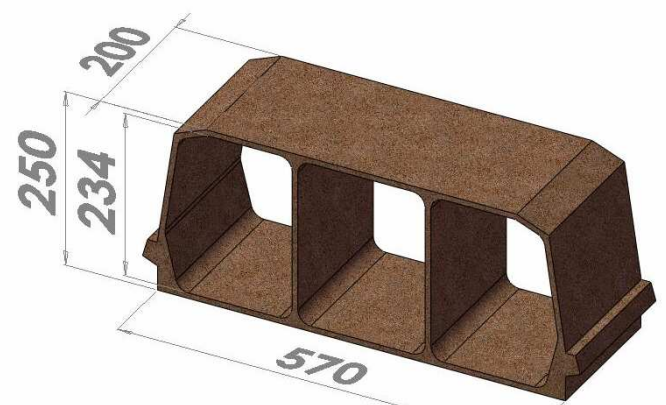

CF1
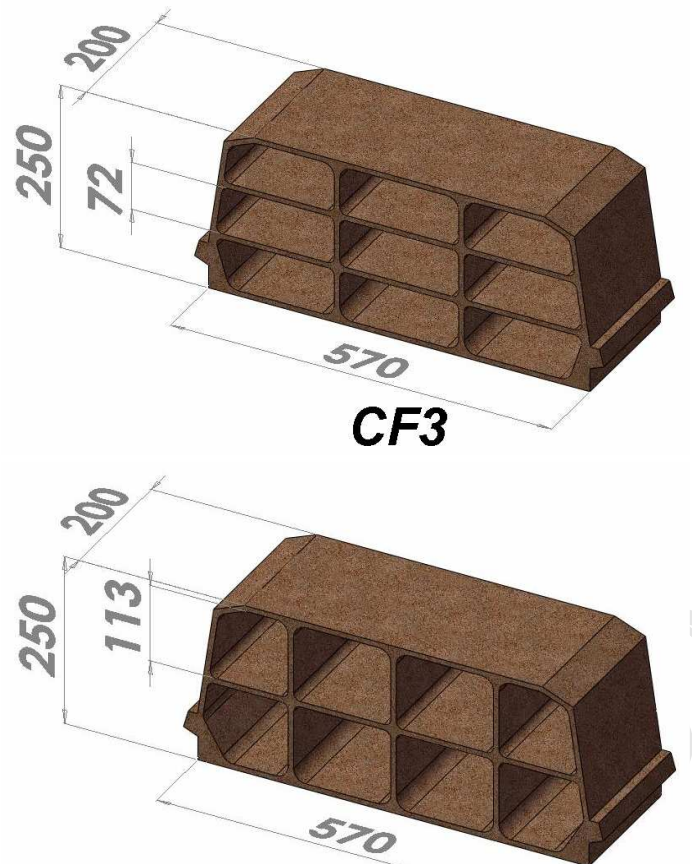

CF5

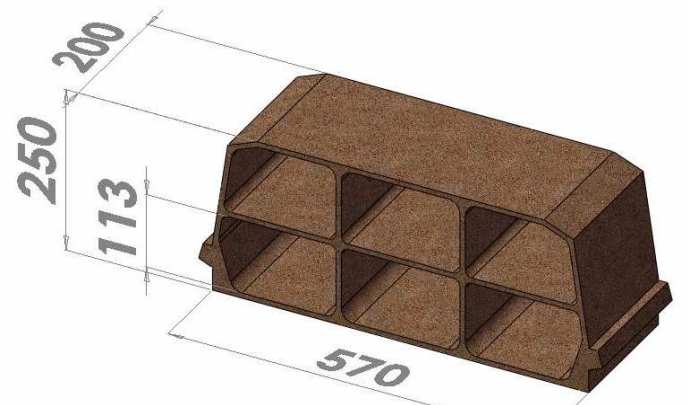

CF2
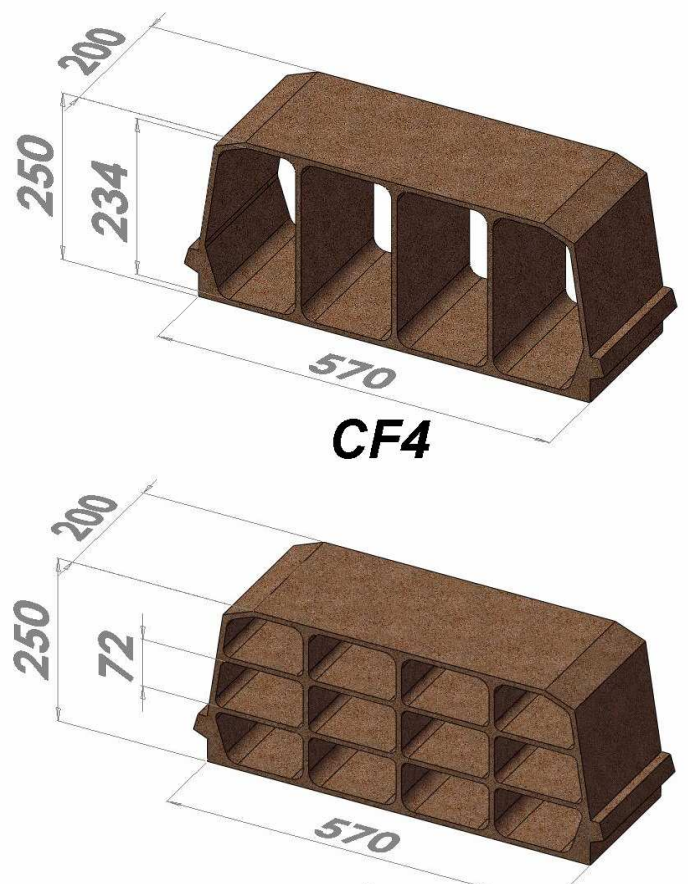

CF6

Fig. 2. Geometrical models and dimensions (in millimetres) of the clay multi-holed blocks $C F 1, C F 2, C F 3, C F 4, C F 5$ and $C F 6$. 
8-node quadrilateral

finite elements

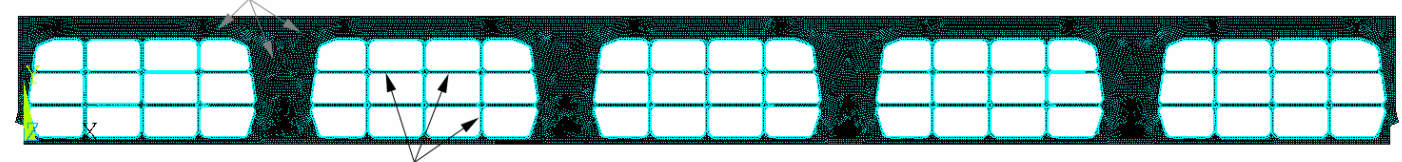

One-dimensional 3-node

finite elements

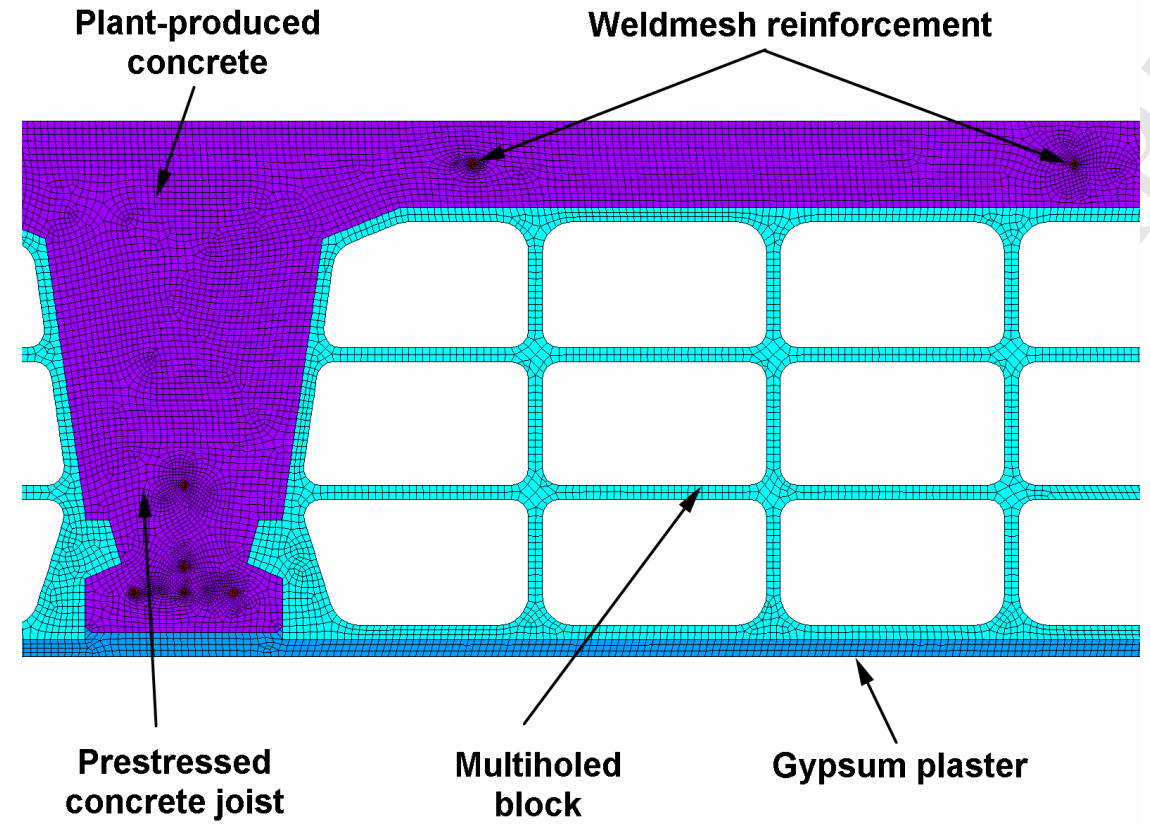

Fig. 3. Two-dimensional FE in situ cast floor: overall view (upper) and a detail (lower). 


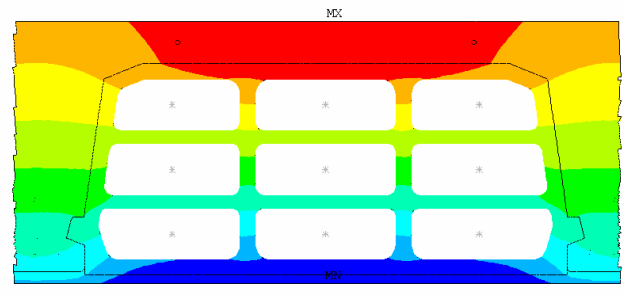

(a)

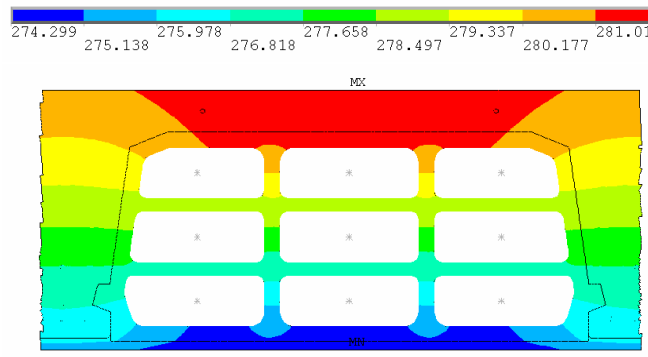

(c)

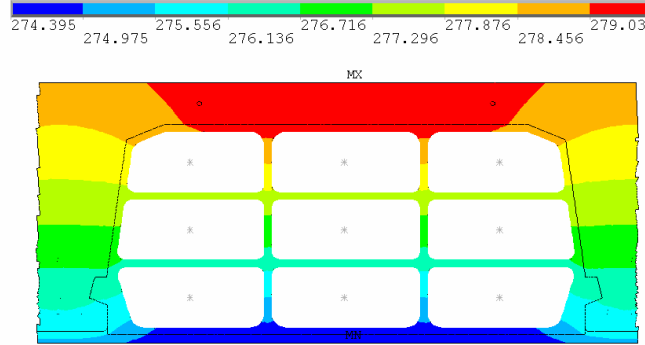

(e)

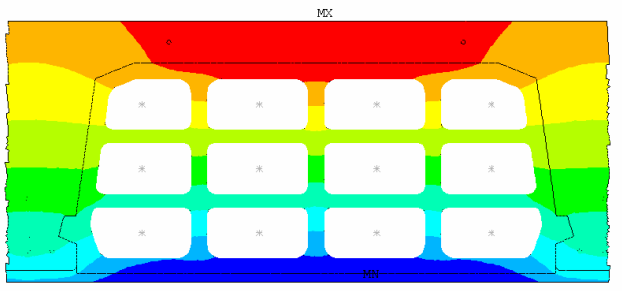

(b)

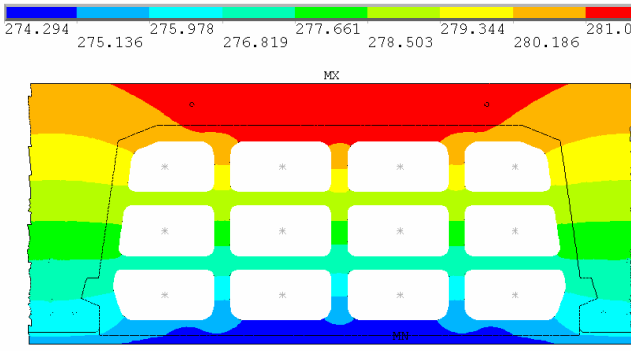

(d)

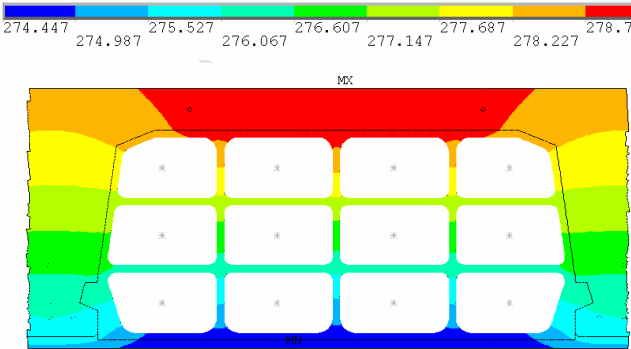

(f)

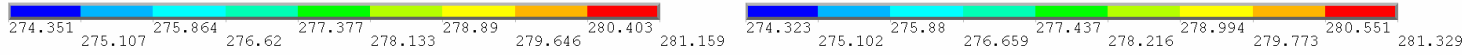

Fig. 4. Temperature distribution in floors made up of hollow block types $C F 3$ (left) and CF6 (right) for the downward heat flow: lightweight concrete (a and b), normal concrete (c and d), and clay (e and f). 

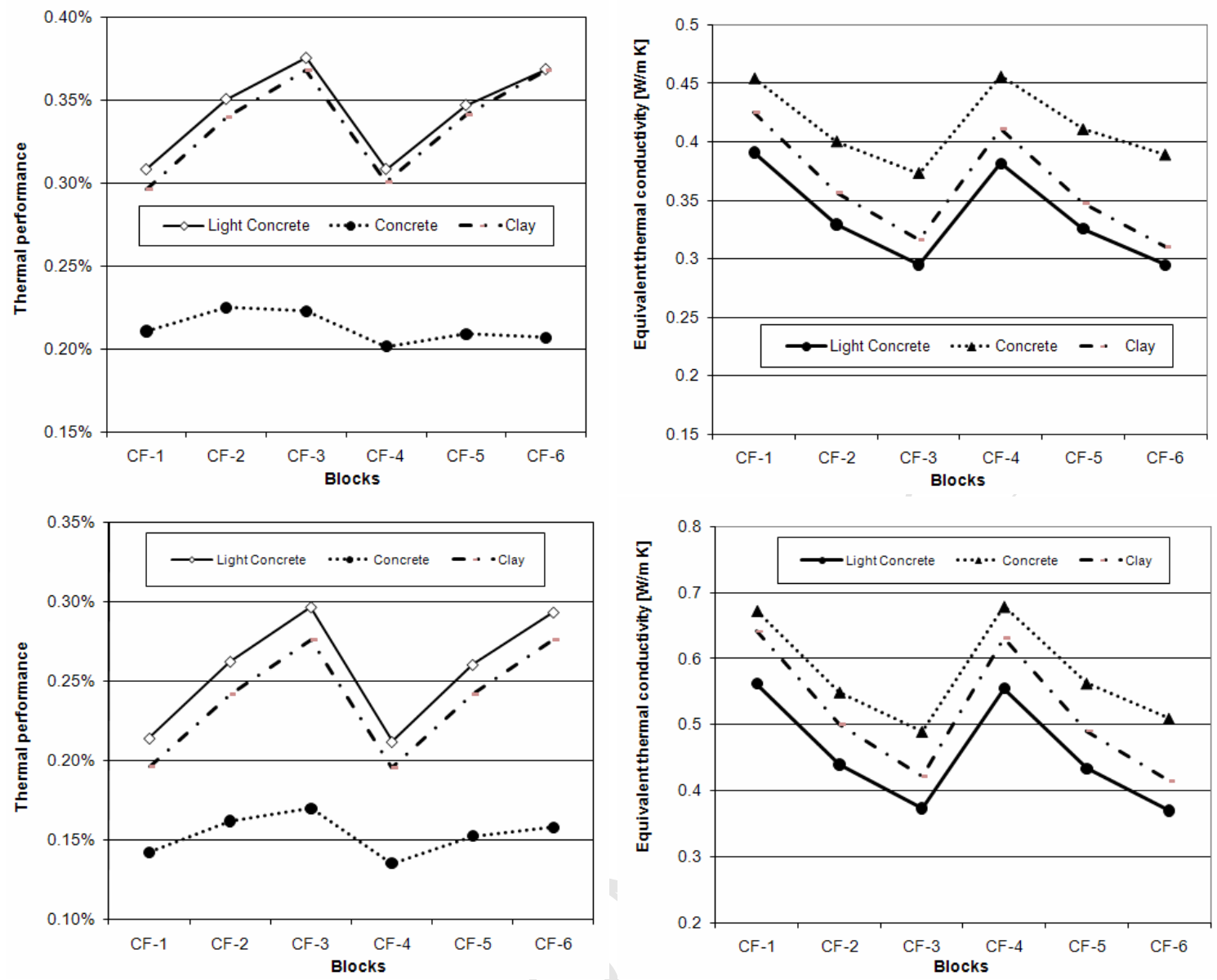

Fig. 5. Mass overall thermal efficiency (left) and equivalent thermal conductivity (right) for downward heat flow (upper) and upward heat flow (lower) for the three analyzed materials and six different models. 